\title{
ANALISIS JABATAN
}

\section{Felix Semaun}

Fakultas Ilmu Sosial dan Ilmu Politik Universitas Kapuas Sintang

Universitas Kapuas Sintang, Jl. Y.C. Oevang Oeray, No.92 Sintang Kalimantan Barat

\begin{abstract}
Abstrak : Analisis jabatan bagian organisasi dan tatalaksana Sekretariat Daerah Kabupaten Sintang sudah dilaksanakan secara optimal melalui pengumpulan informasi analisis jabatan dan aplikasinya menghasilkan uraian jabatan, spesifikasi jabatan dan standar jabatan. Informasi-informasi jabatan meliputi: nama jabatan, kode jabatan, unit kerja rumusan tugas, uraian tugas, bahan kerja, tanggung jawab, wewenang, nama jabatan yang berada dibawah, korelasi jabatan, syarat jabatan, korelasi lingkungan kerja, resiko bahaya dan informasi lainnya.. penggunaan atau aplikasi daripada informasi-informasi analisis jabatan telah berhasil merumuskan uraian jabatan yang relatif lengkap, spesifikasi jabatan masih cukup terkendala dalam hal spesialisasi pendidikan yang ada kurang sesuai dengan tuntutan jabatan, sedang standar kerja yang harus dicapai sudah ralatif lengkap. Faktor-faktor yang mempengaruhi pelaksanaan annalisa jabatan. Faktor internal berupa karakter organisasi Sekretariat Daerah cukup mendukung terutama orang-orangnya, struktur organisasi dan kebijakan-kebijakan yang ada semuanya relatif jelas, demikian juga sistem informasi sudah berjalan sebagaimana mestinya sesuai dengan kemampuan organisasi Sekretariat Daerah. Kendala internal yang masih ditemukan adalah masalah sistem nilai yang dianut oleh pimpinan dengan para bawahan atau pegawai yang berbeda-beda mmengingat dalam hal sistem informasi dan komunikasi, analisa jabatan. Kendala eksternal yang cukup berarti terhadap analisis jabatan adalah kemajuan teknologi informasi dan komunikasi yang begitu cepat, sehingga menjadi kendala untuk menyikapi dan sulit diantisipasi sehingga pegawai tertinggal. Kesimpulan daripada penelitian ini bahwa pelaksanaan annalisis jabatan seacara umum sudah berjalan secara optimal. Faktor-faktor internal yang mendukung adalah kemajuan organisasi dan sistem informasi yang cukup optimal, sedang tantangan internal yang terrkendala adalah sistem nilai yang dianut Pimpinan dan bawahan berbeda-beda dan berdampak pada analisis jabatan di Sekretariat daerah Kabupaten Sintang. Faktor eksternal yang menjadi kendala dalam analisis jabatan adalh teknologi informasi dan komunikasi yang berubah secara cepat, tidak seimbang dengan keterampilan yang dimiliki pejabat. Saran-saran yang diusulkan dalam penelitian ini; Pertama, penyediaan informasi-informasi analisis jabatan perlu terus ditingkatkan. Uraian jabatan perlu disosialisasikan kepada pegawai di lingkungan Sekretariat Daerah untuk menunjang spesifikasi jabatan yang sesuai dengan spesialisasi Pejabat yang tersedia, perlu didukung program pendidikan melalui tugas ijin belajar khusus jurusan yang belum tersedia
\end{abstract}

Kata Kunci: Analisis,Jabatan,Kantor.

Sumber daya manusia merupakan modal dan kekayaan yang terpenting dari setiap kegiatan manusia. Manusia sebagai unsur terpenting mutlak dianalisis dan dikembangkan. Waktu, tenaga, dan kemampuannya benar-benar dapat dimanfaatkan secara optimal bagi kepentingan organisasi maupun kepentingan individu. Sumber daya manusia dalam organisasi merupakan seseorang yang siap, mau, dan mampu memberi sumbangan dalam usaha pencapaian tujuan organisasi. Sumber daya manusia merupakan salah satu unsur masukan (input) yang bersama unsur lain seperti modal, bahan, mesin, dan metode untuk berproses dan menghasilkan keluaran (output) bagi organisasi. Sebelum organisasi melakukan seleksi terhadap karyawan yang akan menduduki jabatan yang baru, maka manajer sumber daya manusia perlu mengetahui dan mengidentifikasi pekerjaanpekerjaan apa saja yang akan dilakukan dan bagaimana pekerjaan dilakukan serta jenis personal yang bagaimana yang layak menduduki pekerjaan tersebut. Adapun hasil dari analisa jabatan dapat berupa deskripsi jabatan (job description) dan spesifikasi jabatan (job specification). Analisis pekerjaan mengumpulkan informasi tentang berbagai karakteristik pekerjaan dan pemegang jabatan. Sebelum mempelajari pekerjaan-pekerjaan, analis perlu memahami organisasi terlebih dahulutujuan, desain,masukan-masukan (sumber daya manusia, material, dan prosedur), dan keluarankeluarannya (produk atau jasa).

Menurut Handoko (2001:43), tahap-tahap analisis pekerjaan "tahap satu persiapan analisis pekerjaan, tahap dua pengumpulan data, tahap ketiga penyempurnaan data". Menurut Handoko (2001:46-51), "penggunaan informasi analisis pekerjaan dapat dikomplikasikan menjadi berbagai bentuk yang berguna seperti deskripsi pekerjaan, spesifikasi pekerjaan, dan standar-standar pekerjaan. Ketiga bentuk informasi analisis pekerjaan ini merupakan informasi sumber daya manusia minimum".Deskripsi pekerjaan 
menguraikan apa yang dilakukan pekerjaan atau profil suatu pekerjaan. Sedangkan spesifikasi pekerjaan menunjukkan siapa yang melakukan pekerjaan itu dan faktor-faktor manusia yang disyaratkan. Standar-standar prestasi kerja memberikan dua manfaat. Pertama standar berfungsi sebagai sasaran-sasaran atau target bagi pelaksanaan kerja karyawan. Tantangan pencapaian sasaran-sasaran bisa memotivasi para karyawan. Kedua standar adalah kriteria dengan mana keberhasilan kerja dinilai atau diukur.

Menurut Hariandja dalam Subekhi (2012:113), "pelaksanaan analisis jabatan berupa pengumpulan informasi mengenai jabatan yang dilakukan dengan kegiatan-kegiatan sebagai berikut: (1) mengidentifikasikan jabatan yang akan dianalisis, (2) menentukan teknik pengumpulan informasi, (3) penggunaan kuesioner". Sedangkan menurut Hasibuan " langkah-langkah analisis pekerjaan adalah sebagai berikut : Menentukan penggunaan hasil informasi analisis pekerjaan.

Mengimpulkan informasi tentang latar belakang.Menyeleksi muwakal (orang yang akan diserahi) jabatan yang akan dianalisis. Mengumpulkan informasi analisis pekerjaan. Meninjau informasi dengan pihak-pihak yang berkepentingan. Menyusun uraian pekerjaan dan spesifikasi pekerjaan.

Meramalkan/ memperhitungkan perkembangan perusahaan.

\section{METODE}

Jenis penelitian ini adalah penelitian deskriptif kualitatif. Adapun yang menjadi subjek atau informan dalam penelitian ini adalah : Sekretaris Daerah kabupaten Sintang, Asisten Administrasi Umum, Kepala Bagian Organisasi dan Tatalaksana, Kepala Sub Bagian Analisa Jabatan dan Pendayagunaan Aparatur, Staf pada Bagian Organisasi dan Tatalaksana.Teknik Pengumpulan Data Wawancara, Observasi, Studi Dokumentasi. Alat Pengumpulan Data yang digunakan dalam penelitian ini adalah : Pedoman Wawancara, Pedoman Observasi, Dokumen. Hasil pengumpulan data dan informasi dianalisis secara seksama. Dalam menganalisis data dan informasi yang ada penulis menggunakan analisis deskriftif kualitatif. Data yang terkumpul diolah dengan mengklasifikasikan sesuai dengan jenisnya yang pada akhirnya disajikan dalam bentuk tabel atau deskripsi apa adanya. Penelitian ini dilaksanakan di Sekretariat Daerah Kabupaten Sintang dengan alasan baik secara metodologis, maupun secara praktis. Secara metodologis pemilihan lokasi penelitian ini cukup beralasan karena pada kantor Sekretariat Daerah Kabupaten Sintang terdapat masalah yang berhubungan dengan analisis jabatan. Dan Sekretariat Daerah Kabupaten Sintang menyediakan data-data yang berhubungan dengan analisis jabatan. Dan salah satu tugas pokok dan fungsi daripada Sekretaris Daerah Kabupaten Sintang melalui Kepala Bagian Organisasi dan Tatalaksana adalah melaksanakan analisis jabatan/ pekerjaan. Secara praktis penelitian ini dilaksanakan di Sekretariat Daerah Kabupaten Sintang khususnya pada Bagian Organisasi, karena lokasi penelitian ini mudah memperoleh data dan mudah terjangkau serta meringankan biaya pelaksanaan penelitian.

\section{HASIL PENELITIAN DAN PEMBAHASAN}

Tahap analisa jabatan di lingkungan Sekretariat Daerah kabupaten Sintang dilakukan melalui tahap persiapan, tahap pengumpulan data, dan tahap penyempurnaan data. Pada tahap persiapan analisa jabatan, menggumpulkan informasi analisa jabatan dengan mencari pedoman organisasi perangkat daerah sesuai dengan ketentuan yang berlaku, kemudian dipadukan dengan tuntutan perkembangan informasi jabatan yang terus berubah. Minimnya informasi yang tersedia dalam hal analisis jabatan pada kenyataannya cukup menyulitkan Para pemangku jabatan dalam memahami dan menjabarkan tugasnya sebagai kepala satuan kerja sehingga sering terjadi hambata yang cukup berarti dalam pelaksanaan tugas. Menurut hasil pengamatan peneliti, bahwa hal yang paling sulit adalah mengidentifikasi pekerjaan dari masing-masing satuan kerja dilingkungan Sekretariat Daerah Kabupaten Sintang maupun perangkat daerah lainnya, disebabkan oleh kurang tersedianya informasi tentang suatu jabatan. Pada tahap pengumpulan data mengenai analisa jabatan dilakukan dengan cara atau metode observasi atau mengamati, metode wawancara dan tanya jawab, dan metode angket atau daftar tentang informasi analisa jabatan. Hasil wawancara dengan Kepala sub bagian analisa jabatan dan pendayagunaan aparatur negara. Jenis data dan informasi yang di kumpulkan dalam analisa jabatan adalah sebagai berikut: Nama jabatan; Kode jabatan; Unit kerja; Rumusan tugas; Uraian tugas; Bahan kerja; Perangkat kerja; Hasil kerja; Tanggung jawab; Wewenang; Nama jabatan; Korelasi jabatan; Syarat jabatan; Kondisi lingkungan; Resiko bahaya; dan Usia jabatan.

Uraian jabatan atau deskripsi jabatan dilingkungan Sekretariat Daerah sudah dilakukan secara tegas dan jelas. Melaui Peraturan Bupati Nomor 28 Tahun 2008 tentang susunan organisasi dan tata kerja dan pedoman uraian jabatan yang dikeluarkan Sekretaris Daerah Kabupaten Sintang.

Adapun nama jabatan yang ada dilingkungan Sekretariat Daerah Kabupaten Sintang Sebagai Berikut: Sekretariat Daerah Kabupaten Sintang terdiri dari 3 Asisten Sekrertaris daerah, 11 Kepala Bagian, dan 26 Kepala Sub Bagian. Menurut 
pengamatan peneliti bahwa setiap asisten Sekretaris daerah membawahi antara tiga hingga empat kepala Bagian, dan Kepala Bagian membawahi dua sampai tiga Kepala Sub Bagian. Bila dikaji dengan ketentuan Peraturan Pemerintah Nomor 08 Tahun 2003 tentang pedoman organisasi daerah yang menyatakan, bahwa "Sekretaris daerah Kabupaten/ Kota terdiri dari sebanyak-banyaknya tiga Asisten Sekretaris Daerah. Asisten Sekretaris daerah terdiri dari sebanyak-banyaknya empat Bagian. Dan setiap Bagian terdiri dari sebanyak-banyaknya tiga Sub Bagian. Berdasarkan keputusan tersebut dapat dinyatakan bahwa penetapan susunan organisasi daerah kabupaten Sintang sudah sesuai dengan ketentuan yang berlaku umum di Indonesia.

Jabatan Sekretaris Daerah uraian tugasnya : . Merumuskan formulasi dan rekomendasi kebijakan sebagai bahan pertimbangan bagi Bupati dalam menentukan kebijakan pemerintah daerah, Mengorganisasikan dinas dan lembaga teknhis daerah dlam rangka penyellenggaraan pemerintahan agar pelaksanaannya dapat berjalan secara terarah, terpadu, selaras dalam memberikan pelayanan kepada masyarakat, Menyusun rencana strategis Sekretariat Daerah yang mengacu pada rencana pembangunan jangka menengah Kabupaten Sintang guna mewujudkan visi dan misi Kabupaten yang telah ditetapkan, Menyusun rencana kinerja tahunan Sekretariat Daerah dan penetapan kinerja berdasarkan rencana strategis Sekretariat Daerah sebagai pedoman dalam melaksanakan kegiatan Sekretariat Daerah, Memberikan arahan kepada para Asisten Sekretaris Daerah dan para Kepala Bagian dalam melaksanakan tugas secara lisan dan tertulis agar pelaksanaan tugas dapat terlaksana sesuai sasaran, Mengendalikan kegiatan bagianbagian di lingkungan Sekretariat Daerah agar pelaksanaannya dapat berjalan sesuai dengan rencana yang ditetapkan, Melakukan pengawasan kepada Para Asisten dan Para Kepala Bagian di lingkungan Sekretariat Daerah, baik secara preventif maupun represif untuk menghindari terjadinya kesalahan dan penyimpangan kesalahan tugas, Mengevaluasi kegiatan yang telah dilaksanakan oleh bagian-bagian di lingkungan Sekretariat Daerah dengan membandingkan hasil kerja yang dicapai dengan rencana kerja yang telah ditetapkan, untuk mengetahui tingkat kinerja yang dicapai, Menelaah konsep naskah yang berkaitan dengan penggunaan dan pengelolaan sumber daya manusia aparatur, kepegawaian, organisasi dan ketatalaksanaan, keuangan, prasarana dan sarana pemerintah daerah berdasarkan pedoman dan ketentuan yang berlaku sebagai bahan pengambilan keputusan, Melakukan pembinaan kepada perangkat daerah dilingkungan Sekretariat Daerah sesuai pedoman dan ketentuan yang berlaku untuk meningkatkan kinerja perangkat daerah, Mengajukan saran dan pertimbangan kepada Bupati dan atau Wakil Bupati baik secara lisan maupun tertulis mengenai permasalahan pemerintahan yang dihadapi serta upaya pemecahan masalah sebagi bahan pertimbangan bagi pimpinan dalam mengambil keputusan, Melaksanakan tugas kedinasan lain yang diberikan oleh Bupati dan Wakil Bupati, Menyampaikan laporan pelaksanaan tugas dan hasilnya kepada Bupati sebagai pertanggung jawaban pelaksanaan tugas, bahan evaluasi serta penilaian kinerja oleh Bupati dan Wakil Bupati.

Jabatan Asisten Administrasi umum (Asisten III), rumusan tugasnya: memimpin pelaksanaan tugas dilingkup Keasistenan administrasi umum dalam rangka membantu Sekretaris daerah merumuskan dan menyusun kebijakan serta petunjuk tekhnis pembinaan, melakukan koordinasi, pengendalian, monitoring, evaluasi dan pelaporan dibidang pengembangan, penataan organisasi dan tata laksana, penyelenggaraan urusan umum Sekretariat Daerah, serta ooperasional sandi, telekomunikasi dan pengolahan data elektronik sesuai ketentuan yang berlaku agar tugas pokok dan fungsi sekretariat Daerah dapat terlaksana dengan efisien dan efektif.

Jabatan Kepala Bagian Organisasi dan Tatalaksana, rumusan tugasnya: memimpin pelaksanaan tugas Bagian Oraganisasi dan Tatalaksana dalam menyiapkan bahan perumusan kebijakan, dna petunjuk tekhnis penataan organisasi dan tatalaksana serta melaksanakan pembinaaan, pengembangan organisasi yang meliputi ketata laksanaan, kelembagaan, analisis jabatan, formasi jabatan, pendayagunaan aparatur, penyusunan LAKIP, RKT dan penetapan kinerja dalam organisasi Sekretariat daerah dan perangkat daerah lainnya sesuai ketentuan yang berlaku agar tugas pokok dan fungsi bagian Organisasi dan Tatalaksana dapat terlaksana secara efektif dan efisien.

Jabatan Kepala Sub Bagian Analisis Jabatan dan Pendayagunaan Aparatur, rumusan tugasnya : Memimpin pelaksanaan tugas sub bagian analisis jabatan dan pendayagunaan aparatur dalam rangka mengumpulkan dan mengolah bahan perumusan kebijakan dan petunjuk teknis, monitoring serta evaluasi penyelenggaraan analisis jabatan, pendayagunaan aparatur, penyusunan formasi jabatan, penyusunan LAKIP, RKT dan penentapan kerja organisasi kesekretariatan dan perangkat lainnya berdasarkan ketentuan dan pedoman yang berlaku agar tugas pokok dan fungsi sub Bagian Analisis Jabatan dan Penadayagunaan Aparatur dapat berjalan efektif dan efisien. Lebih khusus Kepala Sub Bagian Analisis Jabatan menganalisis tentang data jabatan organisasi perangkat daerah, menganalisis data beban kerja jabatan pada organisasi perangkat daerah, melakukan verifikasi hasil analisis jabatan dan analisis beban kerja menyampaikan laporan pelaksanaan tugas dan hasilnya kepada kepala bagian organisasi dana tatalaksana sebagai pertanggung jawaban 
pelaksanaan tugas, bahan evaluasi serta penilaian kinerja oleh pimpinan. Hasil wawancara dengan Kepala sub bagian analisa jabatan dan pemberdayaan aparatur diperoleh informasi bahwa standar kerja sub bagian analisa jabatan dan pendayagunaan aparatur adalah: 1 . Rencana kerja sub bagian analisa jabatan dan pemberdayaan aparatur. 2. Petunjuk kerja kepada bawahan. 3. Pengawasan terhadap bawaahan dalam melaksanakan tugas. 4. Evaluasi terhadap hasil kerja bawahan. 5. Monitoring dan evaluasi pelaksanaan tugas bawahan. 6. Analaisa jabatan organisasi perangkat daerah di lingkungan emerintah Kabuaten Sintang. 7. Analisa data beban kerja jabatan organisasi perangkat daerah di lingkungan pemerintah Kabupaten Sintang. 8. Verivikasi hasil analisis jabatan dan analisis beban kerja para analis. 9. Konsep naskah dinas yang berkenaan dengan penyelenggaraan analisa jabatan, pendayagunaan aparatur, penggunaan LAKIP, RKT, dan penetapan kinerja di lingkup organisasi Sekretariat Daerah Kabupaten Sintang. 10.Bahan sosialisasi, monitoring dan evaluasi penyelengaraan analisa jabatan. 11. saran dan pertimbangan kepada pimpinan. 12. Laporan pelaksanaan tugas.

Spesifikasi jabatan atau tentang siapa yang melakukan jabatan dan faktor manusia yang diperlukan. Persyaratan tersebut menyangkut pendidikan, pelatihan, pengalaman, dan persyaratan fisik dan mental. Syarat-syarat jabatan dilingkungan Sekretariat Kabupaten Sintang harus dipenuhi adalah: 1. Pangkat/golongan ruang, 2. Pendidikan/ jurusan, 3. Kursus/diklat, 4. Pengalaman kerja, 5. Usaha fisik, 6. Kondisi fisik, 7. Bakat yang perlu dimiliki, 8. Minat kerja, 9. Temperamen kerja, 10. Fungsi kerja.

Masing-masing jabatan persyaratan minimal yang harus dipenuhi harus bervariasi antara jabatan yang satu dengan yang lainnya sesuai dengan tingkat jabatan. Aplikasi yang ketiga daripada analisis jabatan adalah standar pekerjaan. Standar pekerjaan memberi manfaat bagi target pelaksanaan kerja seorang pejabat. Standar jabatan juga sebagai kriteria keberhasilan jabatan/pekerjaan. Setiap jabatan dilingkungan Sekretariat Daerah telah ditentukan standar capaian atau hasil kerja yang akan dilakukan setiap pejabat.

Standar kerja yang harus dihasilkan oleh Sekretaris Daerah adalah: 1. Rencana strategis Sekretaris Daerah; 2. Sasaran program yang berkaitan dengan penyelenggaraan tugas pokok Sekretaris Daerah; 3. Perumusan kebijakan dibidang penyelenggaraan Pemerintahan Daerah; 4. Koordinasi kegiatan penyelenggaraan pemerintahan daerah; 5. Pengendalian kegiatan bagian-bagian dilingkungan Sekretariat Daerah; 6. Pengawasan terhadap tugas bawahan; 7. Evaluasi hasil kerja bawahan; 8. Arahan pada Asisten Sekretaris Daerah; 9. Telaahan konsep naskah yang berkaitan dengan pembinaan dan pengelolaan sumber daya manusia aparatur, kepegawaian, organisasi dan ketatalaksanaan, keuangan, sarana dan pra sarana pemerintahan daerah; 10 . Pembinaan dan petunjuk teknis administrasi kepada perangkat daerah dilingkungan Pemerintahan Daerah Kabupaten Sintang; 11. Saran dan pertimbangan kepadaBupati dan Wakil Bupati; 12. Laporan pelaksanaan tugas. Standar kerja atau hasil kerja Asisten III adalah: 1. Rencana kerja Asisten Administrasi; 2. Tealaahan konsep perumusan kebijakan dan petunjuk teknis dibidang pengembangan, penataan organisasi, dan tatalaksana, penyelenggaraan urusan umum, serta operasional sandi, telekomunikasi dan pengolahan data elektronik; 3. Koordinasi kegiatan yang berkenaan dengan bidang tugas ke asistenan Adiministrasi Umum; 4. Pengawasan terhadap tugas bawahan; 5. Evaluasi kerja bawahan; 6.saran dan pertimbangan kepada Pimpinan; 7. Laporan pelaksanaan tugas. Standar kerja yang harus dihasilkan oleh Bagian Organisasi dan Tatalaksana adalah: 1. Rencana kerja bagian organisasi dan tata laksana; 2. Petunjuk kerja kepada bawahan; 3. Pengawasan terhadap pelaksanaan tugas bawahan; 4. Evaluasi kerja bawahan; 5. Konsep rumusan kebijakan; 6. Konsep ppetunjuk teknis; 7. Konsep naskah dinas; 8. Koordinasi dengan unit kerja tekait; 9. Penjelasan dan penyebaran informasi pembinaan kepada masing-masing unit kerja; 10. Saran dan pertimbangan kepada Pimpinan; 11. Laporan pelaksanaan tugas.

Standar kerja Sub Bagian Analaisa Jabatan dan Pemberdayagunaan Aparatur adalah: 1 . Rencana kerja sub Bagian Analisa Jabatan dan Pemberdayagunaan Aparatur; 2. Petunjuk kerja kepada bawahan; 3. Pengawasan terhadap bawahan dalam melaksanakan tugas; 4. Evaluasi terhadap hasil kerja bawahan; 5. Monitoring dan evaluasi pelaksanaan tugas bawahan; 6. Analisis data jabatan organisasi perangkat daerah di lingkungan Pemerintahan Kabupaten Sintang; 7. Analisa data beban kerja jabatan organisasi perangkat daerah dilingkup Pemerintahan Kabupaten Sintang; 8. Verifikasi hasil analisis dan menganalisis beban kerja para analis; 9. Konsep naskah dinas yang berkenaan dengan penyelenggaraan analisis jabatan, penyusunan formasi jabatan, pendayagunaan aparatur, penyusunan LAKIP, RKT, dan penetapan kinerja dilingkup organisasi Sekretariat Daerah Kabupaten Sintang; 10. Sosialisasi, monitoring dan evaluasi penyelenggaraan analisis jabatan; 11.Saran dan pertimbangan kepada Pimpinan; 12. Laporan pelaksanaan tugas.

Dari berbagai informasi tentang standar pekerjaan yang dijelaskan diatas dapat dikatakan bahwa aplikasi dari pada analisis jabatan yang berupa standar hasil kerja yang harus dilakukan oleh pejabat baik Sekretaris Daerah, Asisten Administrasi dan Umum, Kepala Bagian Organisasi dan Kepala Sub Bagian Analisa Jabatan dan Pendayagunaan Aparatur disinyalir sudah dilaksanakan secara optimal. 
Karakter organisasi Sekretariat Daerah memiliki anggota yang terdiri dari pegawai negeri sipil dan pejabat struktural yang terstruktur dalam bagan organisasi. cukup memadainya peralatan dan teknologi, sehingga mendukung pelaksanaan analisa jabatan. Sistem informasi analisa jabatan cukup terkendala oleh berbeelit-belitnya jaringan sistem innformasi antara unit kerja Sekretariat Daerah maupunpada perangkat daerah di pemerintahan kabupaten Sintang. Hal ini akan mempengaruhi terhambatnya aliran sistem informasi analisa jabatan, mmendeskripsi jabatan, spesifikasi jabatan dan standar kerja, karakteristik pegawai yang beraneka ragam turut mmempengaruhi pelaksanaan analisis jabatan, terutama dalam hal prestasi jabatan,masih ada kendala yang cukup berarti.

Faktor internal berupa sistem nilai yang dianut oleh pimpinan dan bawahan yang berbeda-beda atau beragam turut menghaambat objeektivitas proses annalisis jabatan dilingkungan Sekretariat Daeraah Kabupaten Sintang.Menurut Handoko, $(2004 ; 78)$ tantangan bagi manajemen personalia adalah untuk menyelesaikan kegiatan personalia secara proaktif dengan faktor-faktor internal organisasi, baik karakter organisasi, karakter individu, sistem informasi maupun sistem nilai pimpinan dan pegawai. Tantangan dari luar atau eksternal yang paling dominan adalah tantangan teknologi terutama teknologi sistem teknologi informasi dan komunikasi dan pengolah data elektronik, masih menghadapi kendala yang cukup berarti. Dalam tantangan teknologi, juga Peraturan Perundang-undangan yang selalu mengalami perubahan-perubahan akibat reformasi disegala aspek turut mempengaruhi penafsiran-penafsiran yang tumpang tindih dalam analisis jabatan.

Pendapat Handoko (2004), "Bagian personalia perlu memonitor perubahan tantangan eksternal dan merencanakan berbagai tanggapannya". Bagian personalia melakukan pendekatan proaktif terhadap tekanan luar organisasi. Bila dihubungkan dengan kondisi riil internal maupun eksternal pelaksanaan analisis jabatan pada Sekretariat Daerah dapat dikatakan masih sulit mengantisipasi perubahan-perubahan yang terjadi akibat kondisi internal dan eksternal organisasi, sehingga pada gilirannya akan menghambat proses analisis jabatan di lingkungan Sekretariat Daerah Kabupaten Sintang.

\section{KESIMPULAN DAN SARAN}

Pelaksanaan analisis jabatan merupakan salah satu tugas dan fungsi daripada Sekretaris Daerah Kabupaten Sintang .Untuk pelaksanaan lebih lanjut analisa jabatan tersebut, Sekretaris Daerah Kabupaten Sintang dibantu oleh Asisten Administrasi Umum (Asisten III), kemudian asisiten tiga dibanntu oleh Kepala Bagian Organisasi dan Tatalaksana, yang secara tekhnik perasional pelaksanaan analisis jabatan dilakukan atau dibantu oleh Kepala Sub Bagian Analisis Jabatan dan Pendayagunaan Aparatur dilingkungan Sekretariat Daerah Kabupaten Sintang. Secara umum dapat diketahui bahwa pelaksanaan analisis jabatan di lingkungan Sekretariat Daerah Kabupaten Sintang telah berjalan secara optimal. Faktor yang mempengaruhi pelaksanaan analisis jabatan di Sekretariat Daerah Kabupaten Sintang terdiri dari faktor internal dan faktor eksternal. Faktor internal berupa karakter organisasi Sekretariat Daerah cukup mendukung terutama orang-orangnya, struktur organisasi dan kebijakan-kebijakan yang ada semuanya relatif jelas, demikian juga sistem informasi sudah berjalan sebagaimana mestinya sesuai dengan kemampuan organisasi Sekretariat Daerah. Penyediaan informasi-informasi analisis jabatan yang telah berjalan relatif baik perlu terus ditingkatkan. Uraian jabatan atau deskripsi jabatan perlu lebih ditingkatkan dan perlu disosialisasikan sesering mungkin keseluruh unit kerja. Spesifikasi atau syarat-syarat jabatan yang telah ditetapkan perlu didukung oleh program pendidikan dan pelatihan melalui tugas belajar atau ijin belajar bagi jurusan-jurusan yang sesuai dengan tuntutan jabatan. Standar-standar jabatan perlu ditindak lanjuti melalui target dan pelaksanaan yang konsisten oleh Pejabat. 2. Dalam hal faktor eksternal dan aspek karakter organisasi perlu terus ditingkatkan. Perbedaan sistem nilai antara pimpinan dan bawahan atau pegawai perlu diperbaiki melalui pendekatan prrofesionalisme serta kesejahteraan. Kedala eksternal berupa teknologi perlu sikap proaktif untuk mengikut perkembangan kemajuan teknologi melalui pendidikan dan latihan kepada pegawai.

\section{DAFTAR PUSTAKA}

Handoko, Tani. 2002. Manajemen Personalia dan Sumber Daya Manusia. Edisi Kedua, cetakan Kedua, BPFE, Yogyakarta. 2001. Manajemen Personalia dan Sumber Daya Manusia. Edisi Kedua, cetakan Kedua, BPFE, Yogyakarta.

Subekhi, 2012. Pengantar Manajemen Sumber Daya Manusia(MSDM). Penerbit Prestasi Pustaka Raya, Jakarta.

\section{PERATURAN PERUNDANG-UNDANGAN}

Peraturan Pemerintah Republik Indonesia Nomor 10 Tahun 1979 tentang Penilaian Pelaksanaan Pekerjaan Pegawai Negeri Sipil 